\title{
How coloniality generated religious illiteracy in Africa, and how to compensate the situation: Perspectives on Lesotho
}

\begin{tabular}{|c|c|}
\hline \multicolumn{2}{|c|}{$\begin{array}{l}\text { Author: } \\
\text { Rasebate I. Mokotso }{ }^{1,2}\end{array}$} \\
\hline \multicolumn{2}{|c|}{$\begin{array}{l}\text { Affiliations: } \\
{ }^{1} \text { Department of Religion } \\
\text { Studies, Faculty of Theology } \\
\text { and Religion, University of } \\
\text { the Free State, Bloemfontein, } \\
\text { South Africa }\end{array}$} \\
\hline \multicolumn{2}{|c|}{$\begin{array}{l}{ }^{2} \text { Department of Language } \\
\text { and Social Education, Faculty } \\
\text { of Education, National } \\
\text { University of Lesotho, } \\
\text { Roma, Lesotho }\end{array}$} \\
\hline \multicolumn{2}{|c|}{$\begin{array}{l}\text { Corresponding author: } \\
\text { Rasebate Mokotso, } \\
\text { rasebatemokotso@gmail.com }\end{array}$} \\
\hline \multicolumn{2}{|c|}{$\begin{array}{l}\text { Dates: } \\
\text { Received: } 13 \text { Jan. } 2021 \\
\text { Accepted: } 20 \text { May } 2021 \\
\text { Published: } 05 \text { Aug. } 2021\end{array}$} \\
\hline \multicolumn{2}{|c|}{$\begin{array}{l}\text { How to cite this article: } \\
\text { Mokotso, R.I., 2021, 'How } \\
\text { coloniality generated } \\
\text { religious illiteracy in Africa, } \\
\text { and how to compensate the } \\
\text { situation: Perspectives on } \\
\text { Lesotho', HTS Teologiese } \\
\text { Studies/Theological Studies } \\
\text { 77(4), a6468. https://doi. } \\
\text { org/10.4102/hts.v77i4.6468 }\end{array}$} \\
\hline \multicolumn{2}{|c|}{$\begin{array}{l}\text { Copyright: } \\
\text { (C) 2021. The Authors. } \\
\text { Licensee: AOSIS. This } \\
\text { is licensed under the } \\
\text { Creative Commons } \\
\text { Attribution License. }\end{array}$} \\
\hline \multicolumn{2}{|l|}{ Read online: } \\
\hline 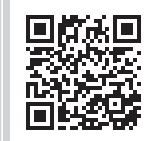 & $\begin{array}{l}\text { Scan this QR } \\
\text { code with your } \\
\text { smart phone or } \\
\text { mobile device } \\
\text { to read online. }\end{array}$ \\
\hline
\end{tabular}

This article debated how coloniality created religious illiteracy in Lesotho. Three parameters were suggested in this regard. Firstly, it is assumed that the prevalence of religious illiteracy started during missionary involvement in Lesotho. Secondly, it is argued that three strategies were applied in this exertion: (1) the missionaries categorised Basotho as being without religion and, therefore, are liable for conversion into religion, which is Christianity. This predisposition ended up in the creation of religion synonymic to Christianity whilst all others disqualified, (2) Basotho were enticed into the binary of religious secularism and privatisation disassociated from spiritualism whilst connected to materialism and private affairs and (3) Basotho were indoctrinated into accepting the existence of one universal religion which is Christianity through Western formal education. Thirdly and finally, decoloniality turn is recommended to curtail illiteracy in religion through the ontology of pluriversality, the hegemony of diversality and the epistemology of pluriversality.

Contribution: The article identified the pervasiveness of religious illiteracy in Africa with special reference to Lesotho. It highlighted its repercussions if left unchecked. Consequently, it examined and put forward the possible causes. As a result of the discoveries, the article suggested procedures to counter the causes in order to promote literacy in religion.

Keywords: Basotho; Christianity; coloniality; decoloniality; pluriversality; religion.

\section{Introduction}

There is pervasive religious illiteracy in the African continent, and more particularly amongst the Basotho as the ethnic focus of this article. By religious illiteracy, borrowing from Moore (2015), it refers to a failure to understand the following about religion:

1) the basic tenets of the world's religious traditions; 2) the diversity of expressions and beliefs within traditions that emerge and evolve in relation to differing social/historical contexts; and 3) the profound role that religion plays in human social, cultural and political life in both contemporary and historical contexts. (p. 1)

From an empirical study conducted by Mokotso and Ntombana (2018:115) in Lesotho, there was a revelation of all the above-mentioned religious illiteracy pointers. The study was conducted amongst religious education teachers as well as the principals of the studied schools. Even the term 'religion' is narrowly conceptualised. It deduced to be synonymous with Christian tradition. Other religious traditions like Hinduism, Islam and Buddhism are cultural representations defining the nationalities of people opposed to Basotho. For example, Hindus are Indians; Muslims represent Arabians, whilst Buddhists are Chinese and Japanese nationals. Although there are certain Basotho who followed some of these religious traditions, they are described as people who are easily misled by other cultures. Their own indigenous religion, which they follow faithfully, does not qualify to be termed 'religion' rather simply the culture that separates them from other ethnicities and nationalities. Their acclaimed religion, which represents Christianity, is conveyed in a binary of privatisation and secularisation. Belongingness to Christian faith is expressed privately by churchgoing and attendance of some religious functions like matrimonies and funerals. Secularly, it provides employment opportunities, more particularly in churchowned institutions (Mokotso \& Ntombana 2018:115).

This situation prompts some concerns, which the current article seeks to unpack. The first question portends why there is prevalence of religious illiteracy amongst the Basotho, in which case it is presumed that it was created by coloniality. The second concern is what the repercussions of religious illiteracy are. In this case, one would agree with Moore (2015:1) that religious illiteracy 
is a catalyst to sociopolitical prejudice and antagonisms. In effect, it hinders the advancement of democratic principles of plurality, coexistence and pursuit for the collective good within the national and international spaces. More specifically, in the African continent, there are observable atrocious manifestations of religious illiterates. For instance, Dube (2020:12) witnessed heinous religious acts performed by leaders of the escalating prophetic movement in Africa. Although Dube's focus was on South Africa, undeniably, one cannot talk about South Africa without Lesotho, and of course the entire continent. Some of these religious leaders or prophets have 'required adherents to eat snakes, drink diesel, and be sprayed with doom' (Dube 2020:12). Followers are deluded to the extent that they cannot ask but yield to the regulatory and abusive acts. Some of these prophets lure adherents through 'fake miracles'. Arguably, these are exhibitions of religious illiteracy on the part of both religious leaders and their following, posing a question of how to promote religious literacy. The proposed strategy towards religious literacy is decoloniality turn.

To engage with these questions of enquiry, the current article employed a qualitative critical literature review (Paré \& Kitsiou 2016:169; Snyder 2019:335) to select both empirical and theoretical literature that responds to the inquest. The information from designated written works was synthesised through critical interpretive analysis to provide answers to these questions. The fundamental purpose was the development of a theoretical framework to the problem of religious illiteracy in Lesotho.

The article envisages desirability of religious literacy to promote the following advanced by Smalley (2018) that:

$[R]$ eligious literacy ... allows people to better understand religion as complex and individual religious traditions as internally diverse and constantly evolving ... [It] also helps us understand how religion has been - and will continue to be - used to justify the full range of human agency from heinous to heroic. (p. 59)

\section{Coloniality assumption}

The assumption of this article is that the prevalence of religious illiteracy in Lesotho represents coloniality. The concept of coloniality differentiates colonial persistence from colonialism that depicts the historical epoch of the presence of colonial administration enforced in colonies (Grosfoguel 2011:15). Colonialism, as Maldonado-Torres (2007:223) remarked, denotes deprivation of economic and political sovereignty of one nation by some other powerful nations. Thereafter, it exploits and misappropriates its economic and human resources. More specifically, it designates Western imperial expansion across other nations of the world through military conquests and consequent political supremacy and despotism. Ashcroft, Griffiths and Tiffin (2007:39-40) explained how colonialism mesmerised its existence. In effect, it coincided in the depth and comprehensiveness of the emergence of the capitalist economic system. Colonies constituted sources of raw materials for the flourishing capital economies of the colonial powers. The relationship between the metropolitan and the colonial periphery was organised around a hierarchical rigidity of political, economic, cultural and societal inequality. Political theory of race became crucial in the construction and naturalisation of the difference between the subject people in colonies and their colonial masters. Ashcroft et al. (2007:39-40) continued to show that colonial subjects were intrinsically inferior, not because they were considered uncivilised, but because of their predetermined biology and intellect. Their subjugation was not merely a matter of political and economic convenience, but constructed as naturally predestined.

However, Maldonado-Torres (2016:10) and Mignolo (2017:3) clarified that colonialism was eradicated through decolonisation, a process of dismantling all forms of colonist power. These include regaining political independence and dismantling other institutionalised and cultured aspects of colonialism. However, Ashcroft et al. (2007:40) posited that although the colonies were able to attain political independence, the institutional and cultural factors that maintained colonialism remained unbroken. The process of holistic decolonisation was resisted by the postcolonised. The champions of decolonisation were cultured and educated into perceiving themselves as resemblances of European education, culture, and political and socio-economic arrangement. They continued to rely on and submit to their post-colonial masters' regulatory systems. Hence, the emergence of the concepts, such as neo-colonialism or new colonialism, denotes the extent to which local élite (comprador) class sustained Eurocentrism and Euro-hegemony.

Subsequently, colonialism and neo-colonialism and their correlatives, decolonisation and post-colonialism represent bygone events. Maldonado-Torres (2016:3) argued that these political and socio-economic incidences characterise past realities or historical occurrences superseded by the contemporary context, replaced by coloniality. Nevertheless, coloniality does not epitomise the aftermath or residual of colonialism, rather operates in dialectic of the past, the middle and the contemporary. It uncovers the plight of colonialism from prior to, during 'classical colonialism' to the present. Instead of merely extending the time for colonial pickles, coloniality intensifies the scope of colonialism. Theoretically, Tlostanova and Mignolo (2009:131-134), Quijano (2007:169) and Bulhan (2015:241) commented that coloniality signifies Eurocentric paradigm typically seeking to defend and validate European hegemonic power (coloniality of power), monopoly of knowledge (coloniality of knowledge) and deformed being of the colonised (coloniality of being). It depicts persistent patterns of power, mode of thinking and behaving that emerged from the contact between European nations, which consider them superior and the others made to accept their inferiority. Coloniality constructs the culture of the colonised as undesirable for modern civilisation and suppresses the colonised modes of knowing and knowledge production. It transforms European culture and systems of knowledge production into aspirations for the colonised. Both are not 
only elevated into colonised ambitions, but also used as means of domination and control (Quijano 2007:169; Tlostanova \& Mignolo 2009:135).

\section{Coloniality and promotion of religious illiteracy in Lesotho}

In the context of Lesotho, coloniality that created religious illiteracy began with the arrival of Protestant French missionaries in the 1830s. The Roman Catholics arrived in the early 1860s and lastly the Anglicans arrived in the late 1870s. There were three missionary tactics that promoted religious illiteracy in Lesotho. The first missionary strategy was cultural imperialism or coloniality of being. Cultural imperialism as defined by Tobin (2007:537) describes the process in which one nation with economic, military and technological superiority forcefully imposes its style of life over another, mainly attacking the target population's cultural aspects. These cultural aspects include customs, traditions, religion, language, social and moral norms and the general worldview. To convert Basotho into Christianity, Manyeli (2001:75-76) explained that missionaries demanded them to give up their way of life, including their traditional religious beliefs, labelled paganism, heathenism, unchristian and irreligion. The missionaries resolved that Basotho were without a religion as one asserted; 'The Basutos, like generally speaking the Kaffirs, possessed no religious knowledge before entering into contacts with the whites' (Laydevant 1935:309). Indeed, the concept 'religion' in Western terms was foreign to Basotho. Basotho like other Africans did not use the concept 'religion' as an organised, institutionalised entity, something which one must be converted into, confess, observe its documented precepts and adapt to its regulated specific way of life (Western civilisation) (Mbiti 1991:3-4). Eventually, Basotho easily accepted the inference because their religion did not match up the characteristics of Western missionary religion. Debatably, since then, the concept 'religion' became and continues to exclusively refer to the White man's religion, that is, Christianity.

Promotion of religious illiteracy was fostered during what Manyeli (2001:78) termed Christian conquest; in this article it refers to as coloniality of power. Coloniality of power started from 1868 when Lesotho became the British protectorate, intensified in 1959 as a complete British colony. Because Basotho did not accede effortlessly to cultural imperialism or coloniality of being, the missionaries connived with the colonists to enforce Western Christianity and civilisation. Manyeli (2001:78-79) and Gill (2010:81) explained how Christian religion and its modus of life (civilisation) were imposed upon Basotho. The newly Christian converts were required to move to the established mission stations away from heathen influence. The proselytes around mission stations enjoyed a relative freedom from traditional rulers, and were rewarded with some colonial favours. The missionaries assumed the responsibilities of issuing passes for government employment in the Cape colony. Those privileged with gaining passes first were the converts. They were, therefore, at advantage to purchase Western goods, adopt the Western life style and civilisation. Government services including health and education were delivered by the missionaries favouring the converts. Generally, as Frankema (2012:336) comments, the British colonists offer positive conditions for missionary work. As a result, Christian converts benefitted more than other groups of the society. Some of the missionaries became government agents like magistrates. Christian converts consistently won court cases, particularly when they involve a Christian against nonChristian. Many of traditional religion beliefs and practices were legally prohibited, and Basotho were forced by law to conform to Western civilisation or Christian life (Gill 2010:82).

These developments, arguably, led to the binary of the secularisation and privatisation of Christian religion. Christian religion became associated with the socio-economic and political benefits disconnected from spirituality. Frescura (2015) confirmed that:

[O]nly $12 \%$ of people on mission settlements were, there for, 'spiritual' reasons. The majority sought either material advantage or psychological security ... Some groups like the Basotho ... welcomed missionaries [mainly for such benefits] ... (p. 66)

It was also privatised through church attendance and participation in Christian ceremonial activities including weddings, funerals and observation of Christian holidays rather than being lived out (Gill 2010:82). Schmidt (2015:2) argued that missionaries used Christianity to promote passivity amongst the Africans. The emphasis was about the virtues of forgiveness, submissiveness and patience. Such selective virtues intended to justify humiliation and suffering endured by Africans under colonial masters. They were encouraged not to worry about the overwhelming distress and humiliation imposed by colonial powers since similar tolerances were beneficial to their good Christian standing. It thus can be argued that such controlling teachings continue even today through the escalating modern prophetic ministry.

Prophetic movement of mythical nature could also be founded on colonial mission myths as Roberts (2012:1-4) noted. The first was the myth of the geographical frontier. Preaching the gospel according to missionaries meant to cross over, discover and conquer the unknown lands. Missionary desire to travel remained a way of avoiding the experiences of radical changes in Western civilisation. The second was the myth of holiness in which the missionaries divided the world into Christians and pagans. Missionaries thought of themselves as both the ambassadors of Christ and the embodiments of the 'Christian way of life'. By doing so, secular forms of holiness were promoted, denying pietism as the true sanctity. The third was the myth of 'the vocation'. Missionary vocation became associated with extensive travel and acquiring knowledge of other lands, the establishments of massive financial business of denominations, bureaucratic structures and White supremacy. These myths had a longlasting Christian legacy on how some African religious leaders perceive themselves. The current prophetic 
movement indisputably exploits such myths. Christian calling means to escape disadvantages of economic deficiency, enjoying a glamorous life, possessing unchallenged power and turning followers into business clientele (Roberts 2012:1-4).

The promotion of religious illiteracy was also through Western formal education, which became a prime cause of 'colonisation of the mind' (in this article, 'coloniality of knowledge'). Although 'colonisation of the mind' as the transmission of mental habits and contents occurred at various social levels, Dascal (2007:4) identified education as a major instrument in this regard. Amongst all ventures of missionary colonisation, the introduction of Western formal education became crucial. Muzvidziwa and Seotsanyana (2002:1) stated that in Lesotho, missionary education was based on Christian teachings. Mission schools developed exclusively to fan out the church doctrine. The introduction of the classroom-based education was a conscious promotion of reading and writing literacy to prepare Basotho for the study of the Bible, Christian values and teachings. Frankema (2012:336) supported that Christian education became an efficient scheme to lure indigenous people into the Christian faith. It contributed to the increased converts over time because educated proselytes were able to spread the Christian religion in the local vernacular. British colonists provided an opportune environment for missionaries of different denominations, and such tendency encouraged denominational competition and, consequently, the increase of missionary schooling supply.

Missionary or colonial education, Dascal (2007:4) depicts, followed what the Brazilian educator Paulo Freire dubbed as the 'banking' model. Banking approach turns knowledge into a commodity that is deposited by those who possess it (the teachers) in the minds of nescience (the pupil). In the process, both are passively involved, the former assuming the role of transmitter and the latter that of absorber. The coloniser assumes to possess all knowledge, whilst the colonised presumes to lack it. This commodity is presumably desired by everybody because of its epistemic properties of truth, universality and benefits. The Christian religion transformed into a commodity through the colonial education system. Basotho who are alleged to be without a religion absorbed it cognitively. Missionary or colonial schooling deposited Christianity as the sole and legitimate religion to learn in a formal education setting. In this epistemic paradigm, Dascal (2007:4) argued that the colonised were coerced to accept their knowledge inferiority, acceding to the superiority of the coloniser's epistemic reasoning. By comparing their belief and reality claim with that of the coloniser, the colonised typically preferred the former's truth-value and consequently adopted it fervently. With this established acceptance, the colonised continue to reject any form of knowledge that contradicts the superior, civilised, desirable knowledge as unwarrantable. This affirms the continuity of Christianity as the sole religion taught in Lesotho schools.

\section{Decoloniality of religious illiteracy in Lesotho}

A decisive strategy to curtail religious illiteracy promoted by coloniality is decoloniality strategy. In this approach, Maldonado-Torres (2016:19) provided a workable scheme involving decoloniality of being, decoloniality of power and decoloniality of knowledge as the constructs of coloniality. The three constructs are inter-related, but separated in this article for clarity. Decoloniality of being focuses on dismantling colonial persistence of dividing and separating human nature into two zones: the 'Zone of being' and the 'Zone of non-being'. In religion, it proposes a shift from the continuous colonial assumption that the beings possess a religion - Christianity - whilst the non-beings are those lacking religion - that is, those without a soul, and therefore merely the damne' or wretched of the earth. The damne' is the being who is 'not there'. As Malay (2010:1) noted, the creation and the use of the category 'religion' accelerated the European negative approach to cultural pluralism, ending up with the development of the so-called uncivilised and unusual societies.

Perpetuating Eurocentric conception of religion as synonymous to Christianity is preserving the colonial legacy that according to Maldonado-Torres (2020) dehumanises the non-Christians and misrepresents Christianity. The nonChristian other characterises someone whose humanity is questioned and therefore liable to a certain degree of political economical and social exploitation. Pluriverse ontology is essential to frustrate such predispositions. Ontology of pluriversity is a strategic response to the domination and fierceness of universalism and Western imperialism. It advocates for pluriversal cosmos where all 'beings' interact, making sense of their existence. Whilst colonialism used religion to differentiate the beings from non-beings, pluriversality conceives all beings with distinct conceptions of religion. As per Querejazu (2016:3), pluriversity refers to multiple ontologies of interconnecting many ways of being in diverse worlds. That is, the existence of religion as a Western construct has different ways of experiences and expression in non-Western worldviews. Therefore, pluriverse, multiple ontologies are not something new or created, but something to be recognised. Draijer-de Jong (2015:1) observed that ' $[n]$ o known society has existed without Religion'.

Decoloniality of power aims to decipher the legacies of colonialism, which promoted religious illiteracy through unequal power relations between the coloniser and the colonised. Coloniality of power in religion rested on Christian hegemony and mythology. Christian hegemony means the power and control as maintained and strengthened through Christian religion. Through Western missionaries and colonists, Christianity became successful in diffusing its particular pattern of social reality and social vision. Its influence assumed a common sense, normal and universal (Blumenfeld 2020:2394), regardless of the existence of other 
religious traditions and worldviews in Lesotho. Blumenfeld (2020:2394) defined Christian hegemony as a systematic approach, granting certain privileges (social, political and economic) to Christians and Christianity. Such benefits were institutionalised as Christian norms or standards, perpetuating the notion that all are or should come to be Christians. As a result, it permits partisan advantage of Christians and Christianity against other religions and worldviews. As Kivel (2013:1-4) argued, Christian hegemony provided and continues to dispense Christian leadership with increased power and control of peoples' vital aspects of life. Their dominance reflects Western missionary or governing elites who used Christianity to justify their expansion of power and wealth. For strategic decoloniality of power, counter-hegemony approach is proposed. Counterhegemony does not complement hegemony, but employed it as a struggle to liberate power-to from power-over (Carroll 2006:19).

Power-to represents a transformational model that alters perpetuation of inequality and inequity. To promote religious literacy, Conway and Singh (2011:22-23) suggested that counter-hegemony of 'diversality' is extremely relevant. Diversality entails accepting co-existence with independent others. It is proportionate to what Maiolino (2011:1-2) refers to as 'agonistic pluralism' that supports the plurality of unavoidable conflict of political notions and values. It espouses the impossibility of achieving a valid rational solution to conflicting claims and the humanising of vicious conflict or 'antagonism'. In consequence, diversality rejects universalisation of any religion that usurps power over others, but grants power to all religions through a humanising antagonism. Diversality does not constitute a rational ground on which a universal consensus could be achieved. Rather, it is structured by a vigorous but mutually tolerant contest amongst groups of people, united by passionately shared identifications.

Decoloniality of knowledge attempts to demystify the colonial education system that created illiteracy in religion. It means challenging and confronting the colonising practices that have produced and continue to reproduce religious education. A Western school system continues to use Christian religion to perpetuate colonisation of the mind, the heart and the spirit. To confront colonial education constructs, Mignolo (2007:17) suggested epistemological decoloniality constituting an environment that permits intercultural and interchange of religious experiences and meanings. Such effort is possible through epistemic delinking. The concept 'delinking' for Imasato (2010:131) remains both analytic and methodological. Analytically, it aids in the understanding of the epistemic impositions of colonialism and its practical and political effects. Epistemic delinking, Mignolo (2017) posits, highlights the blindness of Western knowledge to acknowledge other valid and necessary epistemologies in its quest for universalism and power. Methodologically, to delink does not necessarily mean to dessert or to put aside, on the contrary, to bring forth other epistemologies into play
(Imasato 2010:131). It does not reject Western body of knowledge, but recognises its inevitability and relevance. At the same time, it admits its potential dangerousness whilst sustaining its historical aims in the established epistemic power of the universal knowledge (Mignolo 2017).

Whilst Christian religion is necessary and relevant, its misrepresentation within the Western coloniality education paradigm renders it a contributing factor to religious illiteracy. What is needed for the promotion of religious literacy, as (Stojnić 2017:109-110) proposes, is epistemic pluriversality or border thinking. Epistemic pluriversality presupposes many worlds where there is co-existence of pluri-epistemologies that offer possibilities for interepistemic modes of knowledge. Its purpose is the abolition of the hierarchies of separate epistemologies, where one regards itself superior, modern and valid, whilst the other regards itself inferior, barbaric and unscientific. Pluriversality or border thinking is typically a reaction against geo- and bodypolitics epistemology distinguishing itself from inferiority or devilishing others. It is, however, the epistemology of 'exteriority' operating from the outside whilst developed from inside. The position of pluriversity represents religious pluralism, which is the teaching, and learning that admits plurality of religious knowledge from the pluriversal experiences of different beings and worldviews (Stojnić 2017:109-110).

\section{Conclusion and recommendation}

The discussion made in this article poses the solution to the problem of religious illiteracy in Lesotho's context theoretically (decoloniality approach). There is a need for practical strategies that would essentially contribute to the promotion of religious literacy. Within pluriversal decolonial discourse, religious literacy entails (Parker 2020):

$[T]$ he ability to discern and analyse the fundamental intersections of religion and social/political/cultural life through multiple lenses. A religiously literate person is described as possessing: a basic understanding of the history, central texts (where applicable), beliefs, practices, and contemporary manifestations of several of the world's religious traditions as they arose out of and continue to be shaped by particular social, historical, and cultural contexts and the ability to discern and explore the religious dimensions of political, social and cultural expressions across time and place. Crucially, the religiously literate person will understand religions and religious influences in context and as inextricably woven into all dimensions of human experience. (p. 129)

The assertion points to the reality of the advancement of greater religious literacy directed not only to religious groups, or to make people more religious or even to determine the positive aspect of religion. Preferably, it should aim at developing a better understanding of religion in order to further dialogue, cohesion and a more inclusive society (All Party Parliamentary Group on Religious Education 2019:48). Practical strategies, therefore, should espouse both school- and community-based initiatives, that is, transformative Praxis. 


\section{Acknowledgements Competing interests}

The author declares that he has no financial or personal relationships that may have inappropriately influenced him in writing this article.

\section{Author's contributions}

R.I.M. is the sole author of this research article.

\section{Ethical considerations}

This article followed all ethical standards for research without direct contact with human or animal subjects.

\section{Funding information}

This research received no specific grant from any funding agency in the public, commercial or not-for-profit sectors.

\section{Data availability}

Data sharing is not applicable to this article as no new data were created or analysed in this study.

\section{Disclaimer}

The views and opinions expressed in this article are those of the author and do not necessarily reflect the official policy or position of any affiliated agency of the author.

\section{References}

All-Party Parliamentary Group on Religious Education, 2019, Improving religious literacy: A contribution to the debate, viewed 16 November 2020, from https:// publications.parliament.uk.

Ashcroft, B., Griffiths, G. \& Tiffin, H., 2007, Post-colonial studies: The key concepts, Routledge, New York, NY.

Blumenfeld, W.J., 2020, 'Challenging Christian hegemony and Christian privilege in academia', in R. Papa (ed.), Handbook on promoting social justice in education, pp. 2388-2416, Springer, Cham.
ppar

Bulhan, H.A., 2015, 'Stages of colonialism in Africa: From occupation of land to occupation of being', Journal of Social and Political Psychology 3(1), 239-256. https://doi.org/10.5964/jspp.v3i1.143

Carroll, W.K., 2006, 'Hegemony, counter-hegemony, anti-hegemony', Journal of the Society for Socialist Studies 9-43.

Conway, J. \& Singh, J., 2011, 'Radical democracy in global perspective: Notes from the pluriverse', Third World Quarterly 32(4), 689-706. https://doi.org/10.1080/01436 597.2011.570029

Dascal, M., 2007, Colonizing and decolonizing minds, viewed 16 November 2020, from www.alhassanain.org/english.

Draijer-de Jong, A.M., 2015, 'Reviewing the premise: "No society has existed without religion": Soul beliefs; causes and consequences', viewed 10 October 2020, from https://www.academia.edu/12401211.

Dube, B., 2020, "Go and prophesy in your own land": Foreign prophets and popularism in South Africa. Evoking the need of Jonathanic theology for peaceful resolution of difference', Religions11(42), 1-12. https://doi.org/10.3390/rel11010042

Frankema, E.P., 2012, 'The origins of formal education in sub-Saharan Africa: Was British rule more benign?', European Review of Economic History 16(4), 335-355. https://doi.org/10.1093/ereh/hes009

Frescura, F., 2015, 'A case of hopeless failure: The role of missionaries in the transformation of Southern Africa's indigenous architecture', Journal for the Study of Religion 28(2), 64-86.
Gill, S.T., 2010, A shourt history of Lesotho, Morija Museum \& Archives, Morija.

Grosfoguel, R., 2011, 'Decolonizing post-colonial studies and paradigms of politicaleconomy: Transmodernity, decolonial thinking, and global coloniality', Transmodernity: Journal of Peripheral Cultural Production of the Luso-Hispanic World 1(1), 1-38. https://doi.org/10.5070/T411000004

Imasato, T., 2010, 'Delinking legitimacy: A decolonial critique of Brazilian ethanol', Critical Perspectives on International Business 6(2/3), 128-144. https://doi. org/10.1108/17422041011049950

Kivel, P., 2013, What is Christian Hegemony?, viewed 13 November 2020, from www. christianhegemony.org.

Laydevant, F., 1935, 'Idee de Dieu chez les Anciens Basutos', Revue de Universite d'Ottawa 309-330.

Maiolino, A., 2011, 'Agonistic pluralism: The right compass on the long way to counter hegemony?', In Meeting the author with Chantal Mouffe, Zürich, 15 December 2011 - 16 December 2011. https://doi.org/10.5167/uzh-54754

Malay, A., 2010, 'How colonialism created “religion?" Introduction: Imagining and appropriating categories', viewed 21 December 2020, from http://faculty.smcm. edu/jwschroeder.

Maldonado-Torres, N., 2007, 'On the coloniality of being: Contributions to the development of a concept', Cultural Studies 21(2), 240-270. https://doi. org/10.1080/09502380601162548

Maldonado-Torres, N., 2016, 'Outline of ten theses on coloniality and decoloniality [Interview] (22 August 2016)', Steve Biko Center, King Williams's Town.

Maldonado-Torres, N., 2020, 'Religious studies and/in the decolonial turn', viewed 12 December 2020, from https://contendingmodernities.nd.edu.

Manyeli, T., 2001, 'A critical analysis of missionary strategy in Lesotho', in L.B.B.J. Machobane \& T.L. Manyeli (eds.), Essay on religion and culture among Basotho,1800-1900, pp. 64-101, Mazenod Publishers, Mazenod.

Mbiti, J., 1991, African religions and philosophy, Heinemann Educational Publishers, Oxford.

Mignolo, W., 2017, 'Key concepts [Interview] (21 January 2017)', viewed 29 November 2020, from https://www.e-ir.info/pdf/67501.

Mignolo, W.D., 2007, 'Epistemic disobedience: The de-colonial option and the meaning of identity in politics', Niterói 1(22), 11-41.

Mignolo, W.D. \& Tlostanova, M.V., 2006, 'Theorizing from the borders: Shifting to geoand body-politics of knowledge', European Journal of Social Theory 9(2), 205-221. https://doi.org/10.1177/1368431006063333

Mokotso, R.I. \& Ntombana, L., 2018, Religious pluralism for inclusive education in Lesotho senior secondary schools: Religio-educational approach, Incwadi Press, Cape Town.

Moore, D.L., 2015, 'Overcoming religious illiteracy: A cultural studies approach', World History Connected 4(1), 1-14.

Muzvidziwa, N.V. \& Seotsanyana, M., 2002, 'Continuity, change and growth: Lesotho's education system', viewed 11 October 2020, from http:// radicalpedagogy.icaap.org.

Parker, S., 2020, 'Religious literacy: spaces of teaching and learning about religion and belief', Journal of Beliefs and Values 41(2), 129-131, https://www.tandfonline. com/doi/full/10.1080/13617.

Paré, G. \& Kitsiou, S., 2016, 'Methods for literature reviews', in F. Lau \& C Kuziemsky (eds.), Handbook of eHealth evaluation: An evidence-based approach, pp. 157-180, University of Victoria, Victoria.

Querejazu, A., 2016, 'Encountering the pluriverse: Looking for alternatives in other worlds', Revista Brasileira de Política Internacional 59(2), 1-16. https://doi. org/10.1590/0034-7329201600207

Quijano, A., 2007, 'Coloniality and modernity/rationality', Cultural Studies 21(2), 168-178. https://doi.org/10.1080/09502380601164353

Robert, D.D., 2012, “'Rethinking missionaries” from 1910 to today', Methodist Review CVIII(4), 57-75.

Schmidt, B., 2015, 'Christianity as a double-edged sword in colonial Africa', viewed 26 November 2020, from https://scholarworks.bgsu.edu/Africanstudiesconf/ 2015/004/1.

Smalley, P., 2018, 'Reflections on the progress of developing religiously literate citizens in England', Professional Reflection. Theory and Practice 36(1), 58-63.

Snyder, H., 2019, 'Literature review as a research methodology: An overview and guidelines', Journal of Business Research 104, 333-339. https://doi.org/10.1016/j. jbusres.2019.07.039

Stojnić, A., 2017, 'Power, knowledge, and epistemic delinking', AM Journal 14, 105-111.

Tlostanova, M. \& Mignolo, W., 2009, 'Global coloniality and the decolonial option', Kult 6, 130-147. https://doi.org/10.25038/am.v0i14.218

Tobin, T., 2007, 'Cultural imperialism', in E. Robert \& W. Kolb (eds.), Encyclopedia of business ethics and society, pp. 537-541, Sage Publications, Thousand Oaks, CA. 